INDEPENDENT JOURNAL OF MANAGEMENT \& PRODUCTION (IJM\&P)

http://www.ijmp.jor.br

v. 11, n. 6, September - October 2020

ISSN: 2236-269X

DOI: 10.14807/ijmp.v11i6.1170

\title{
PRICE-FORMING FACTORS CHOICE GROUNDING AT INTANGIBLE ASSETS WITH NEGATIVE DEPRECIATION INDEPENDENT VALUATION/APPRAISING
}

\author{
Yuri Vladimirovich Pozdnyakov \\ Ukrainian Appraisers Association Member, Ukraine \\ E-mail: jerzy.pozdniakow@gmail.com \\ Skybinska Zoryana \\ National University «Lviv Polytechnic», Ukraine \\ E-mail:szm@ukr.net \\ Gryniv Tetiana \\ National University «Lviv Polytechnic», Ukraine \\ E-mail:gtans@ukr.net \\ Submission: 11/9/2019 \\ Revision: $12 / 3 / 2019$ \\ Accept: 3/20/2020
}

\section{ABSTRACT}

Independent expert valuation/appraising of intellectual property rights objects, such as brands and goodwill, performed by the Costs approach, is based on economic indicators of these intangible assets utility degree, which are connected with the sum of all expenses, related to appraised asset creation and support. These indicators are used as a primary data for these intangible assets market value determination. All these indexes are differently related to the brand value, and relationship between these parameters researches, indisputably, presents both theoretical and practical interest. Because of the cross-correlation relationship closeness between assets market value and these primary data parameters directly depend estimation results accuracy and reliability. The work is verification of basic hypothesis, in obedience to that at the brands valuation/appraising procedure performing as primary data may be recommended to use those indicator parameters, which are characterized with the closest statistical relationship and, respectively, the highest cross-correlation coefficient. Research is based on fact that these intangible assets are able to change their value characteristics in both directions, and change the annual depreciation sign during the separate periods of economic life, made it positive or negative. 


\section{INDEPENDENT JOURNAL OF MANAGEMENT \& PRODUCTION (IJM\&P)}

http://www.ijmp.jor.br

v. 11, n. 6, September - October 2020

ISSN: 2236-269X

DOI: 10.14807/ijmp.v11i6.1170

The purpose of the article is to define the quantitative estimations of cross-correlation relationship strength between economic parameters, which are used as primary data source in Costs approach, and estimated brand value; to perform the comparative analysis of crosscorrelation relationship density between the brand value, appraised as intellectual property object, and these economic parameters, that are used as the main price-forming factors; researching and approbation of methodology, based on this cross-correlation relationship closeness quantitative indexes determination, on the certain examples of brands evaluation. Finally, the main purpose is to set the parameter, for which the correlation coefficient is the highest, and which is most expedient to use as primary data source at economic measurements performing.

Keywords: intellectual property; brand name; trademark; goodwill; independent valuation/appraising; accounting; market value; intangible assets; sign-changed Depreciation/Obsolescence

\section{INTRODUCTION}

Valuation results high uncertainty degree in intellectual property objects value economic measurements, performed by independent expert evaluation methods, requires the urgent decision of evaluation methodical base improvement problem solving. It's well-known that applied econometrics conclusions are characterized by the high level of subjectivity, so estimations and prognoses executed by two specialists even with the identical theoretical skills level will differ (MAGNUS; KATYSHEV; PERESECKIJ, 2004).

In our opinion, the decline of subjective constituent of the general economic measurements error is possible by statistical methods wider applying to primary market information data processing in evaluation procedure. In particular, at Costs approach application to intangible assets evaluation a various market information data are used, that are based on the economic indicators of enterprises activity.

Different indexes in a different degree are related to the brands market value, and from the closeness of cross-correlation relationship between these parameters estimation results accuracy and reliability depends directly. In this work we go out of supposition, that at Costs approach application it's most appropriate to use those parameters, which are most closely statistically related with a measureable value index of intellectual property objects.

We also take into account that the brand name, after it became popular for consumers and business partners, brings to the enterprise not only economic preferences, but also deserved 
DOI: 10.14807/ijmp.v11i6.1170

public confession and high consumers respect. Therefore an absolute title value of brand using must be considered not only as an object of intellectual property that has a fully certain market value index, but also as important intangible asset advantage (FARHUTDINOV; TRAPEZNIKOV, 2006), which is the main part of enterprises goodwill basis.

Performing economic measurements of intellectual property objects market value is one of the most difficult tasks of independent expert evaluation, the methodological basis of which has not been adequately developed so far. This is due, first of all, to the existing contradictions between the actual value changing in time functions and assumptions, regulated by the standards of financial accounting. In particular, the latter only provide the possibility of objects', that are valued and accounted as intangible assets, cost decreasing over time only while, in fact, brand value of successful companies is growing rapidly during their economic life.

This testifies the presence of negative depreciation occurrences in this class intellectual property objects, along with the traditional generally accepted positive depreciation in certain periods of time. As our previous studies have shown, different depreciation sign can be manifested in certain periods of brands' existence, and the depreciation sign may change many times, in strictly accordance with changes in the trend of these assets value increasing or decreasing (POZDNYAKOV, 2019; POZDNYAKOV; LAPISHKO; SKYBINS'KA, 2019).

In intellectual property rights objects, such as brands and goodwill, at evaluation/appraising by Costs approach some economic indicators are used - mostly, annual and accumulated during the whole retrospective period advertisement expenses indexes. These indicators are widely used as a primary data for brands market value determination - but, despite this, objective quantitative estimations of cross-correlation relationship closeness between these economic parameters were not determined before.

Contradiction and incompleteness of given data in the various sources, concerning the problem of relationship between the indexes of annual and accumulated during the entire retrospective period Selling, General and Administrative Expenses (SG\&A) indexes and enterprise brand value, appraised as a value of operating business, makes actual the question of relationship character that links these indexes, quantitative determination and further research of statistical relationship closeness and cross-correlation coefficients.

Therefore determination and comparative analysis of these indexes are the actual task of independent evaluation methodology further development. Research of the theoretical and 
DOI: 10.14807/ijmp.v11i6.1170

practical aspects of higher formulated scientific problem has a great practical importance, because indexes are named higher have direct influence on economic measurements results uncertainty degree and its errors size. Its research on the concrete examples of intellectual property objects evaluation will give an opportunity to ground mathematically strictly the choice of primary market information data parameters, which are most closely associated with a measureable market value index.

\section{LITERATURE REVIEW}

The researches by Ray R. Gehani established that corporate brand value is one of the most important strategic assets that companys must manage, so it's necessary re-examine the age-old tradition of building corporate brand values based on corporate identity, legacy, and stakeholder interactions. It can be performed by using a more appropriate research methods of grounded theory approach coupled with case studies, quantitative and qualitative data (GEHANI, 2016).

Brands and trademarks are the most widely used form of intellectual property with nearly 7 million trademark filings worldwide in 2016 as opposed to less than 3.1 million patent filings. Economic efficiency of these intangible assets does not cause any doubts: trademark use causes the stock quotations positive dynamics, and the published researches results specify on extraordinarily strong correlation of this asset cost with the business increase indexes in innovative economy (FINK et al., 2018).

Trademarks and goodwill, which are very specifically intellectual property types of intangible assets, are able to change their market value both in the direction of decrease, what means positive depreciation, and also in the increase direction - what means negative depreciation. So, during the economic life period their market value may vary in both directions, demonstrating alternating sign-changeable depreciation. For successful enterprises brands there is a general tendency to increase their value over time, accordingly with enterprises appraised value - which means a negative depreciation of both parameters.

But the characteristics of the value change in time of assets listed above, used in accounting documents, do not correspond to the actual value time changes. Annual depreciation/amortization indicators, are still used in book-keeping, accounting and financial reports documents, very often suggests brand value reduction over time only. In fact, it is growing rapidly in the same time - but accounting standards and rules does not take into 
DOI: 10.14807/ijmp.v11i6.1170

account the possibility of these intangible assets value factual increase, i.e. the negative depreciation presence (POZDNYAKOV; LAPISHKO, 2019a).

Earlier we formulate the conclusion about the inexpediency to use the accounting data for depreciation/amortization in trademark value determination, executed by the Costs approach/Compared Sales approach combination methods. That's because book-keeping, accounting and financial reports documents data are only the consequence of the completely conditional rules for assets accounting use, set by the normative regulatory framework for the financial statements. It was proved that these data are not related to factual changes of intellectual property objects market value (POZDNYAKOV; LAPISHKO, 2018a; POZDNYAKOV; SADOVENKO, 2018a).

Often there are paradoxical situations when value of intellectual property objects is reduced, according to the accounting data of depreciation/amortization, and evaluation monitoring practice in the same time confirms the fact of its value multiple increase. For the independent evaluation, when the Costs approach/Compared Sales approach combination is applying, we can state absolute inappropriateness of accounting data considering for this kind of intellectual property objects valuation (POZDNYAKOV; LAPISHKO, 2018b). So, the correct choice of adequate indicator, which determines the relationship between price-forming factors and the appraised brand value, is the pressing problem of today.

Gordon V. Smith specifies on the substantial importance of relationship characteristics between the enterprise incomes and intangible assets that are belonged to it (SMITH, 1999). At this class of intellectual property objects market value determination as price-forming factors the indexes of annual and accumulated expenses on its advertising and information support are used (DAMODARAN, 2009). The extremely high level of estimation errors in brands independent expert evaluation was educed in our previous works (POZDNYAKOV; SADOVENKO, 2018b; POZDNYAKOV; SADOVENKO, 2018c). Some correlations and relationship characteristics of absolute and relative estimation errors were also researched (POZDNYAKOV; SADOVENKO, 2019; POZDNYAKOV; LAPISHKO, 2019b; POZDNYAKOV; LAPISHKO, 2019c; POZDNYAKOV; SKYBINS'KA; GRYNIV, 2019).

In our point of view, complications of reliable econometric independent expert evaluation performing of these kind intangible assets is related, first of all, with the contradictions between the real dynamics law of its value changes in time and absolutely voluntary postulated suppositions in relation to these law conformities, that are used at the 
DOI: 10.14807/ijmp.v11i6.1170

financial account of enterprises assets and regulated by corresponding standards (POZDNYAKOV; LAPISHKO, 2018b).

Unfortunately, book-keeping accounting standards presuppose only possibility of intangible assets value indexes reduction (or, at last, constant stability) in time. But in fact market value of successful companies' brands rapidly grows during its economic life term. It testifies the negative depreciation unique possibility presence of these intellectual property objects, which is opposite to the traditional generally accepted positive depreciation of other assets. As it is showed in our previous researches, the sign-changed depreciation is shown up in separate periods of brands economic existence time.

Moreover, depreciation sign can change frequently, in accordance with the trends change of market value increase or reduction. So, brands and goodwill, which are very specifically intellectual property types of intangible assets, are able to change their market value both in the direction of decrease, what means positive depreciation, and in the direction of increase - what means negative depreciation. During the economic life period their market value may vary in both directions, demonstrating alternating sign-changeable annual depreciation (POZDNYAKOV; LAPISHKO, 2018a; POZDNYAKOV; LAPISHKO, 2019a).

\section{RESEARCH METHODOLOGY AND THEORETICAL BACKGROUND}

The general methodological base of the article is scientific and special for the subject sphere of scientific cognition knowledge methods, typical for econometrical researches. The choice of methodological approaches is conditioned by the specific of the economic measurements, which are executed by independent expert appraising/valuation methods. The research is grounded on mathematical simulation and mathematical statistic quantitative methods. Research methodology also envisages generalization of previous publications results from scientifically-research sources and open sources statistic information about the enterprises activity economic indicators. Basic principles of independent expert appraising/valuation also made the general methodological basis of the article, in particular - principles of Utility, Substitution and The Highest and The Best Use. To the certain methods of research belongs the method of cross-correlation analysis and time value of money theory elements.

Foremost, it is necessary to define mathematically strictly the indexes of appraised assets depreciation. With an aim of more complete exposure of brand value change in time function character, we analyze the absolute index of $\mathrm{A}_{\text {pas i }}(t)$ - annual depreciation for each $i$ 
DOI: 10.14807/ijmp.v11i6.1170

year of retrospective period. It is determined as an absolute annual intangible asset value increase, is taken with a reverse sign, and is measured by a dimension of monetary items:

$$
A_{\text {раз і }}(t)=-A_{\text {рпв і }}(t) \text {, }
$$

where $A_{\text {рпв i }}(t)$ - absolute annual appraised intangible asset value increase, which is determined by the formula

$$
\mathrm{A}_{\text {рпв і }}(t)=V_{i}-V_{i-1},
$$

where $V_{i}$ - an index of the appraised intangible asset value in $i$ year (for example, on the valuation date);

$V_{i-1}$ - an index of the appraised intangible asset value in previous $(i-1)$ year.

Equation (1), taking into account formula (2), can be written as

$$
\mathrm{A}_{\text {раз } \mathrm{i}}(t)=V_{i-1}-V_{i} .
$$

From the mathematical point of view an annual absolute depreciation is the statistical analogue of the first derivative of appraised asset value change in time function. Duration of one year period in this index determination is selected only due to practical application comfort considerations. In fact, in general case, this period can be certain fully arbitrarily, in dependence on the necessities of concrete research task.

Therefore in more general case instead the use of concrete term "annual" it is expedient to apply more exact term - "periodical". It is clear that an index of annual absolute depreciation always is the time function and, theoretically, it can be certain on any, arbitrarily select, interval of time. Therefore at the necessity of more detailed analysis of investigated parameter dynamics there can be used indexes of depreciation for shorter periods - for example, for a quarter, for a month, and others like that, up to daily absolute depreciation.

It is easy to prove that than shorter will be duration of period $\Delta \mathrm{t}$ at periodical depreciation $A_{\text {раз }}(t)$ determination, for each $i$ period, then anymore its numeral values will be more close to the value of the $A_{\text {раз }}(t)$ function first derivative:

$$
\lim _{\Delta t \rightarrow 0} A_{\text {раз }}(t)=\frac{\partial V_{\mathrm{i}}(t)}{\partial t} .
$$

Inflection points of $V_{i}(t)$ asset value change in time $t$ function, in that it changed increase to decrease trends, or otherwise, id est - changed the sign of its the first derivative, are according to zero value of its first derivative, determined by (4). So, zero $A_{\text {раз } i}(t)$ values in 
DOI: 10.14807/ijmp.v11i6.1170

these moments accept the indexes of periodical depreciation, when value change in time function shows a transition through abscise axis. Therefore an annual depreciation can be examined as a measuring index of $V_{i}(t)$ asset value change in time $t$ function dynamics. Actually this very useful feature of the offered index of periodical depreciation grounds to consider it as an optimal and most comfortable instrument for the evaluation tasks solution, that are related to the asset value change in time $t$ function.

Let we notice that index of periodical depreciation $A_{\text {pasi }}(t)$ simultaneously is also an indirect measuring index of $\mathrm{A}_{\text {паз }}(t)$ complete accumulated depreciation function dynamics. This parameter shows quantitative estimation of complete depreciation, accumulated in a period from zero time to $t$ time, id est - from the moment when an appraised asset was created/purchased and put on accounting balance. As the index of the complete accumulated depreciation in $i$ period we mean taken with a reverse sign absolute complete increase of appraised intangible asset value, on the interval of zero time from the date of its creation (acquisition) to the valuation date:

$$
A_{\text {паз і }}(t)=-A_{\text {ппв і }}(t) \text {, }
$$

where $A_{\text {ппв i }}(t)$ - absolute complete accumulated appraised intangible asset value increase in $i$ year (for example, on the valuation date), which is determined by the formula

$$
\mathrm{A}_{\text {ппв і }}(\mathrm{t})=V_{i}(\mathrm{t})-V_{0},
$$

where $V_{i}(\mathrm{t})$ - an index of the appraised intangible asset value in $i$ year (for example, on the valuation date);

$V_{0}$ - an index of the appraised intangible asset primary value in zero year (period), according to date of its creation (acquisition).

Just like (3), equation (5), with taking into account (6), can also be written in next modification:

$$
\mathrm{A}_{\text {паз } \mathrm{i}}(\mathrm{t})=V_{0}-V_{i} .
$$

The indexes of depreciation, are certain in described higher character, are the most concrete and the most complete descriptions that can be applied for the objective quantitative analysis of $V_{i}(t)$ appraised asset value change in time $t$ function dynamics. Next we use calculation values and graphic diagrams of brands annual absolute depreciation to achieve an evident presentation of brands appraised value dynamics, that in general case is characterized 
DOI: 10.14807/ijmp.v11i6.1170

by the presence of long-time duration periods of negative annual depreciation and short-time periods of positive annual depreciation (POZDNYAKOV, 2019).

We go out from a supposition that from the closeness of cross-correlation relationship between price-forming factors and measureable parameter - the brand value index - estimation result accuracy and reliability depends. Thus, the basic hypothesis of research is fixed about expedience of those price-forming factors application at evaluation procedure, which are most closely constrained with intellectual property objects measureable parameter. The quantitative measure of statistical relationship closeness between these two investigated parameters is a correlation coefficient, that is why in future research we use the mathematical base of crosscorrelation analysis.

It gives an opportunity to analyze quantitative interdependence between these two groups of economic parameters that is constrained not functionally, but statistically. Unlike functional one, cross-correlation relationship shows up only as a probability index for the certain array of supervisions. In the theory of cross-correlation analysis pair and plural correlation are distinguished, but in this case we investigate statistical relationship between only two groups of indexes, that is why we limited to linear pair correlation coefficient determination. The mathematical function type of pair correlation is set by quality analysis of economic connections between two groups of the researched parameters and its graphic image as the cross-correlation field.

The cross-correlation field shows a points set totality in the rectangular coordinates system; abscissa each of that points answers to the value of factor sign, and ordinate - to the value of effective sign. Taking into account the theoretically reasonable ground presence of casual relationship between the sizes of annual and accumulated advertisement expenses with appraised brand value, next we will consider the first of these parameters as a factor sign, and the second, accordingly, as effective sign.

The amount of points set totality on the chart of the cross-correlation field answers the amount of supervision units. The regression line orientation on the cross-correlation field specifies the presence of direct (increasing function) or reverse (falling function) relationship between researched parameters; the degree of marks variation on the field in relation to the regression line gives an idea about the relationship closeness degree, or its absence; the form of marks cloud dispersion, and also the form of regression line, shows a function kind, by which it is possible to approximate statistical dependence. 
DOI: 10.14807/ijmp.v11i6.1170

With the aim of research the presence and descriptions of statistical interconnection between the first and second investigated parameters groups we will define the quantitative index of this relationship closeness. Being based on the cross-correlation regressive model, that envisages the linear statistical dependence presence, will determine the linear coefficient of pair correlation that is widely used in econometrics for two parameters relationship closeness. Let's specify mathematical calculation principles of linear pair correlation coefficient $\mathrm{R}$ between two rows of parameters on the example of two discrete rows of $V_{1}, V_{2}$ parameters, where $V_{1}$ is a factor sign numeral value, and $V_{2}$, accordingly, effective sign value:

$$
R=\frac{\overline{\mathrm{V}_{1} * \mathrm{~V}_{2}}-\overline{\mathrm{V}_{1}} * \overline{\mathrm{V}_{2}}}{\sigma\left(\mathrm{V}_{1}\right) * \sigma\left(\mathrm{V}_{2}\right)}
$$

where $\mathrm{V}_{1}$ - numeral value of factor sign - annual and accumulated advertisement expenses,

$\mathrm{V}_{2}$ - numeral value of effective sign - appraised brand value,

$\overline{\mathrm{V}_{1}}, \overline{\mathrm{V}_{2}}$ - numeral mathematical expected values estimations of factor and effective signs discrete rows;

$\overline{\mathrm{V}_{1} * \mathrm{~V}_{2}}$ - numeral mathematical expected value estimation of factor and effective signs products discrete row;

$\sigma\left(\mathrm{V}_{1}\right), \sigma\left(\mathrm{V}_{2}\right)$ - standard deviations of factor and effective signs discrete rows, determined by the indexes of its sample variance (selective dispersion) estimations:

$$
\begin{aligned}
& \sigma^{2}\left(\mathrm{~V}_{1}\right)=\frac{1}{l} \sum_{i=1}^{l}\left(\mathrm{~V}_{1 \mathrm{i}}-\overline{\mathrm{V}_{1}}\right)^{2}, \\
& \sigma^{2}\left(\mathrm{~V}_{2}\right)=\frac{1}{l} \sum_{i=1}^{l}\left(\mathrm{~V}_{2 \mathrm{i}}-\overline{\mathrm{V}_{2}}\right)^{2},
\end{aligned}
$$

where $l$ - an amount of these discrete rows members in investigated selection, in this case $l$ is determined by a sample size (SIVEC, 2001, p. 102).

For the small sample selections the sample variance estimations of selective dispersion, got after the formulas given higher, often appear biased, that is why in such cases more expedient is application of the corrected sample variance:

$$
\begin{aligned}
& \sigma^{2}\left(\mathrm{~V}_{1}\right)=\frac{1}{l-1} \sum_{i=1}^{l}\left(\mathrm{~V}_{1 \mathrm{i}}-\overline{\mathrm{V}_{1}}\right)^{2}, \\
& \sigma^{2}\left(\mathrm{~V}_{2}\right)=\frac{1}{l-1} \sum_{i=1}^{l}\left(\mathrm{~V}_{2 \mathrm{i}}-\overline{\mathrm{V}_{2}}\right)^{2},
\end{aligned}
$$


DOI: 10.14807/ijmp.v11i6.1170

Standard deviation is the absolute measure of the investigated data discrete row variation, and it is the quantitative determinant of data series heterogeneity degree. But it depends on the row separate members absolute level and, accordingly, on its arithmetic mean value (mathematical expected value estimation). Therefore direct comparison of different data series rows by standard deviation indexes is not possible, and for possibility of such comparison the relative index of series heterogeneity degree - coefficient of variation is used

$$
k=\frac{\sigma(\mathrm{V})}{M(\mathrm{~V})} \times 100 \%
$$

where $M(\mathrm{~V})$ - data series row mathematical expected value estimation.

The numeral values of pair correlation linear coefficient can be calculated also by other method - after a formula that takes (9), (10) into account (LAPISHKO, 1995, p. 88).

$$
R=\frac{\frac{1}{l} \sum_{\mathrm{i}=1}^{\mathrm{l}}\left(\mathrm{V}_{1 \mathrm{i}}-\overline{\mathrm{V}_{1}}\right) *\left(\mathrm{~V}_{2 \mathrm{i}}-\overline{\mathrm{V}_{2}}\right)}{\sqrt{\frac{1}{l} \sum_{\mathrm{i}=1}^{\mathrm{l}}\left(\mathrm{V}_{1 \mathrm{i}}-\overline{\mathrm{V}_{1}}\right)^{2} * \frac{1}{l} \sum_{\mathrm{i}=1}^{\mathrm{l}}\left(\mathrm{V}_{2 \mathrm{i}}-\overline{\mathrm{V}_{2}}\right)^{2}}},
$$

In the end, formulas (8) and (14) are only the variants of more general expression

$$
R=\frac{\operatorname{cov}\left[\mathrm{V}_{1}, \mathrm{~V}_{2}\right]}{\sqrt{\operatorname{var}\left[\mathrm{V}_{1}\right] * \operatorname{var}\left[\mathrm{V}_{2}\right]}}
$$

where $\operatorname{cov}\left[\mathrm{V}_{1}, \mathrm{~V}_{2}\right]$ - it is a covariance of factor $\mathrm{V}_{1}$ and effective $\mathrm{V}_{2}$ signs data series rows,

$\operatorname{var}\left[\mathrm{V}_{1}\right]$ and $\operatorname{var}\left[\mathrm{V}_{2}\right]$ - it is a variation of factor $\mathrm{V}_{1}$ and effective $\mathrm{V}_{2}$ signs data series rows (BOJARSKIJ, 1972, p. 18).

Covariance of factor $\mathrm{V}_{1}$ and effective $\mathrm{V}_{2}$ signs data series discrete rows is determined as

$$
\operatorname{cov}\left[\mathrm{V}_{1}, \mathrm{~V}_{2}\right]=\overline{\mathrm{V}_{1} * \mathrm{~V}_{2}}-\overline{\mathrm{V}_{1}} * \overline{\mathrm{V}_{2}},
$$

or

$$
\operatorname{cov}\left[\mathrm{V}_{1}, \mathrm{~V}_{2}\right]=\frac{\sum_{\mathrm{i}=1}^{\mathrm{l}}\left(\mathrm{V}_{1 \mathrm{i}}-\overline{\mathrm{V}_{1}}\right) *\left(\mathrm{~V}_{2 \mathrm{i}}-\overline{\mathrm{V}_{2}}\right)}{l},
$$

and variation of factor $\mathrm{V}_{1}$ and effective $\mathrm{V}_{2}$ signs data series discrete rows, accordingly, are equal to the sample variance estimations of selective dispersion indexes after formulas (9), (10):

$$
\operatorname{var}\left[\mathrm{V}_{1}\right]=\frac{1}{l} \sum_{i=1}^{l}\left(\mathrm{~V}_{1 \mathrm{i}}-\overline{\mathrm{V}}_{1}\right)^{2}
$$


DOI: 10.14807/ijmp.v11i6.1170

$$
\operatorname{var}\left[\mathrm{V}_{2}\right]=\frac{1}{l} \sum_{i=1}^{l}\left(\mathrm{~V}_{2 \mathrm{i}}-\overline{\mathrm{V}_{2}}\right)^{2} .
$$

After the formulas given higher were determined rows indexes of brands appraised value dynamics and brands annual absolute depreciation. Also were obtained the next rows indexes of factor and effective signs: minimum and maximum of sign range; data series row mathematical expected value estimations; sample variance estimations of selective dispersion and corrected selective dispersion indexes; standard deviation estimations; coefficient of variation; linear coefficient of pair correlation; coefficient of determination. These parameters were researched for few wide world most valuable brands with the aim to obtain quantitative characteristics of statistical relationship interdependence closeness between selected priceforming factors and intellectual property objects measureable parameter - appraised brand value index.

\section{CONDUCTING RESEARCH AND RESULTS}

\subsection{Brand Samsung}

Samsung Electronics Co., Ltd is multinational electronics company, established in 1969 and headquartered in Suwon, South Korea. Samsung had market leadership position in businesses which include the mobile communications, TV, memory chip businesses (KUMAR, 2015). Being a global world brand, Samsung annually spends large expenses on an advertisement, marketing and advancement of the products market promotion. In 2017 Samsung expended in an advertisement KRW 5,4 trln of and KRW 7,3 trln on sales promotion. Its expenses on products advertisement in 2016 estimated as KRW 4,4 trln, and charges on sales promotion made KRW 7,3 trln.

Next we use the primary data about expenses on the Samsung Electronics company advertisement, given in (PRATAP, 2019), with no taking into account annual charges on sales promotions, that is also related to brand market value forming. Primary market information data about appraised brand value were published by Interbrand company (INTERBRAND, 2018).

On a figure 1 the trends of appraised brand value time change dynamics and brand annual absolute depreciation on retrospective period 2010 - 2018 are shown. 
ISSN: 2236-269X

DOI: $10.14807 /$ ijmp.v11i6.1170
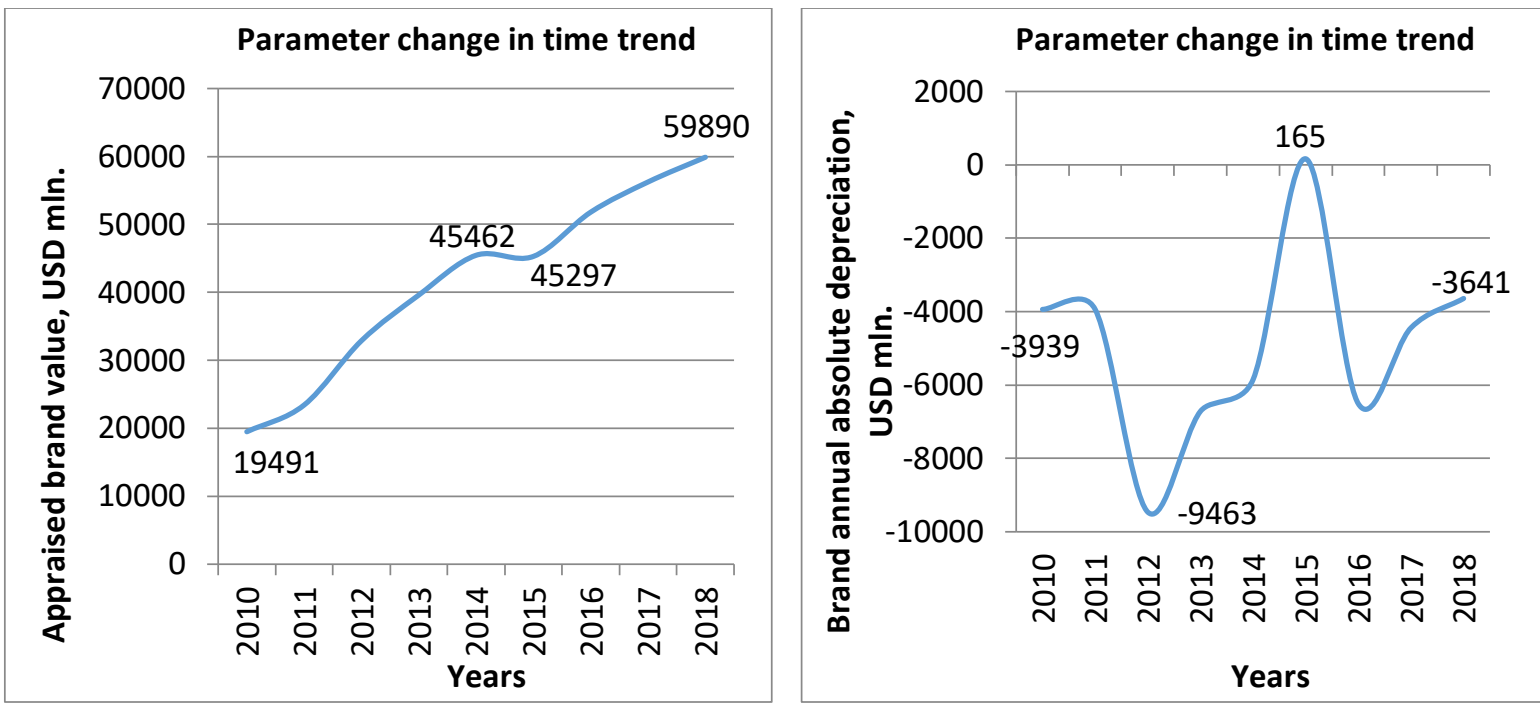

Figure 1: Appraised brand value dynamics (left) and brand annual absolute depreciation on retrospective period (right).

Source: diagrams are developed by the authors.

Let's consider more detailed appraised brand value changes dynamics on a long-term duration interval. As we can see from a diagram on figure 1 (left), according to Interbrand specialists evaluation results, during a retrospective period is observed almost monotonous increase of appraised brand value - after one exception: in 2015 it took place its insignificant decline to 45297 USD mln from an index in previous 2014, that presented 45462 USD mln. Thus, brand value changes dynamics volatility took place in a wide range, that is determined by the change of brand annual absolute depreciation index: from - 9463 USD mln in 2012 to 165 USD mln in 2015.

From shown in figure 1 (right) diagram, we can see that brand annual absolute depreciation index during a long-term duration retrospective period carried out signchangeable character. Researched brand annual absolute depreciation indexes were mainly negative, that corresponds to this intangible asset value increase in this period. But exactly in 2015 it took place its temporal short-term decline, which led to appearance of positive annual absolute depreciation index. This example is good illustration of such a special intellectual property objects class, as brands, trademarks and goodwill, ability to demonstrate alternating character of annual absolute depreciation during the term of its economic life.

With the aim of relationship character research between the indexes of annual / accumulated during the whole retrospective period advertisement expenses and appraised brand value we will consider the cross-correlation statistical interdependence of these primary data sources. On figure 2 (left) graphic interpretation of annual advertisement expenses dynamics in time is presented. On figure 2 (right) correlation field of accumulated during the 
INDEPENDENT JOURNAL OF MANAGEMENT \& PRODUCTION (IJM\&P)

http://www.ijmp.jor.br

v. 11, n. 6, September - October 2020

ISSN: 2236-269X

DOI: 10.14807/ijmp.v11i6.1170

whole retrospective period advertisement expenses and appraised brand value, with regression line equation characteristics and determination coefficient value, are shown.
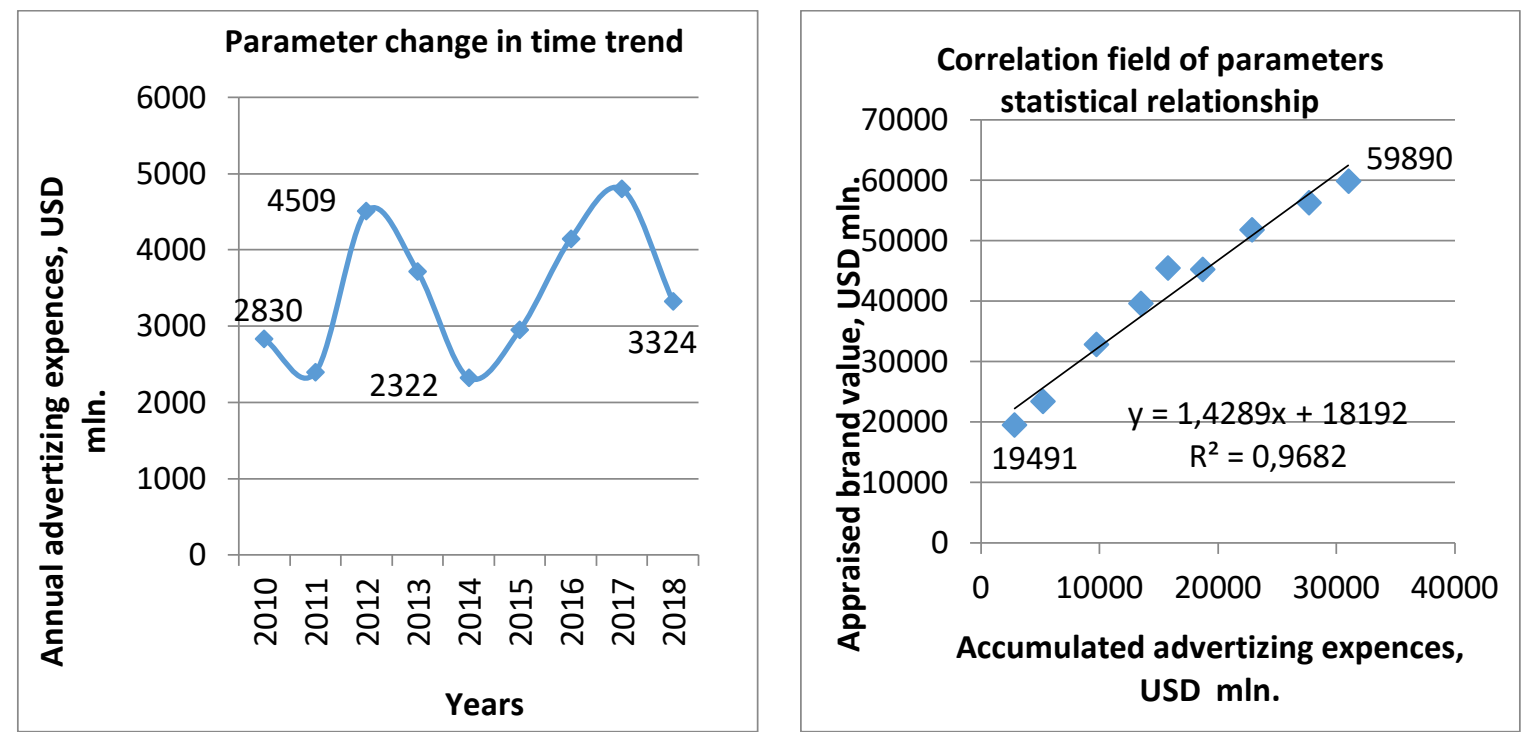

Figure 2: Annual advertisement expenses dynamics (left) and correlation field of accumulated during the whole retrospective period advertisement expenses and appraised brand value (right).

Source: diagrams are developed by the authors.

As we can see, the fall-off of annual advertisement expenses in period from 2012 to 2014 almost twice, from 4509 USD mln to 2322 USD mln, resulted in accordingly fall-off of the appraised brand value already in a next time period. Thus the educed tendency of annual advertisement expenses cutting during two consecutive years had the unavoidable consequences not only of appraised brand value increase rates deceleration, but even its cost reduction in absolute expression.

Actually this annoying fact is represented by appearance in 2015 positive value of annual absolute depreciation index, one and only time during the investigated retrospective period. It confirms the rightness of the hypothesis about close statistical relationship interdependence between annual advertisement expenses charges and appraised brand value. Therefore it is possible to expound fully reasonable supposition, that if the sharp annual advertisement expenses reducing did not take place during two consecutive years in period from 2012 to 2014, then violation of general tendency of appraised brand value increase would not take place.

\subsection{Brand Pepsi}

Marketing innovations are a key driver in soft drinks industry, as a competition in this industry of industry is very high, and trademarks compete mainly in area of marketing. Both 
DOI: 10.14807/ijmp.v11i6.1170

leading brands - Coca Cola and Pepsi - invest large expenses in marketing, aggressively to advertise own commodities and trademarks. Next we use market primary data about the allocated advertisement expenses of PepsiCo company, given in (PRATAP, 2018), where a considerably larger general marketing budget of PepsiCo, in that these allocated advertisement expenses are not included. Data about the appraised brand value are published by Interbrand company (INTERBRAND, 2018). On diagrams figure 3 the trends of appraised brand value time change dynamics and brand annual absolute depreciation on retrospective period 2003 2018 are shown.
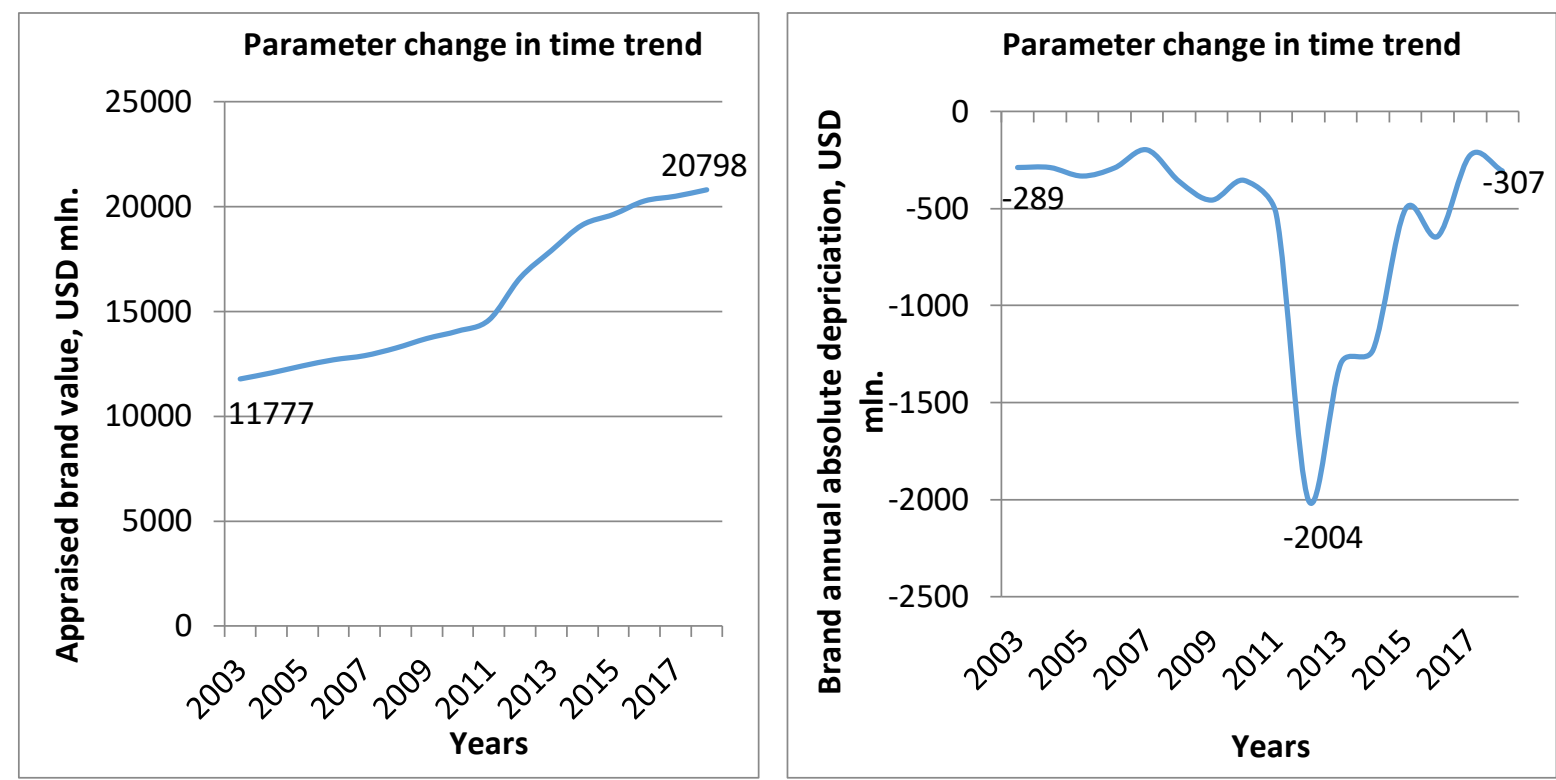

Figure 3: Appraised brand value dynamics (left) and brand annual absolute depreciation on retrospective period (right).

Source: diagrams are developed by the authors.

As we can see from a diagram on figure 3 (left), during a retrospective period 2003 2018 absolutely monotonous increase of appraised brand value is observed, with no any exception. Thus it follows to mark the considerable volatility of appraised brand value increase rates. From brought in a figure 3 (right) time changes trend of brand annual absolute depreciation index is evidently, that the increase rates of this intangible asset appraised value were changed sharply, but the general tendency of annual increase of its cost remained unchanging. The negative values of brand annual absolute depreciation index are predefined by stable value increase during the whole retrospective period.

On figure 4 (left) graphic interpretation of annual advertisement expenses dynamics in time is presented; on figure 4 (right) correlation field of accumulated during the whole retrospective period advertisement expenses and appraised brand value, with regression line equation characteristics and determination coefficient value, are shown. 
DOI: $10.14807 /$ ijmp.v11i6.1170
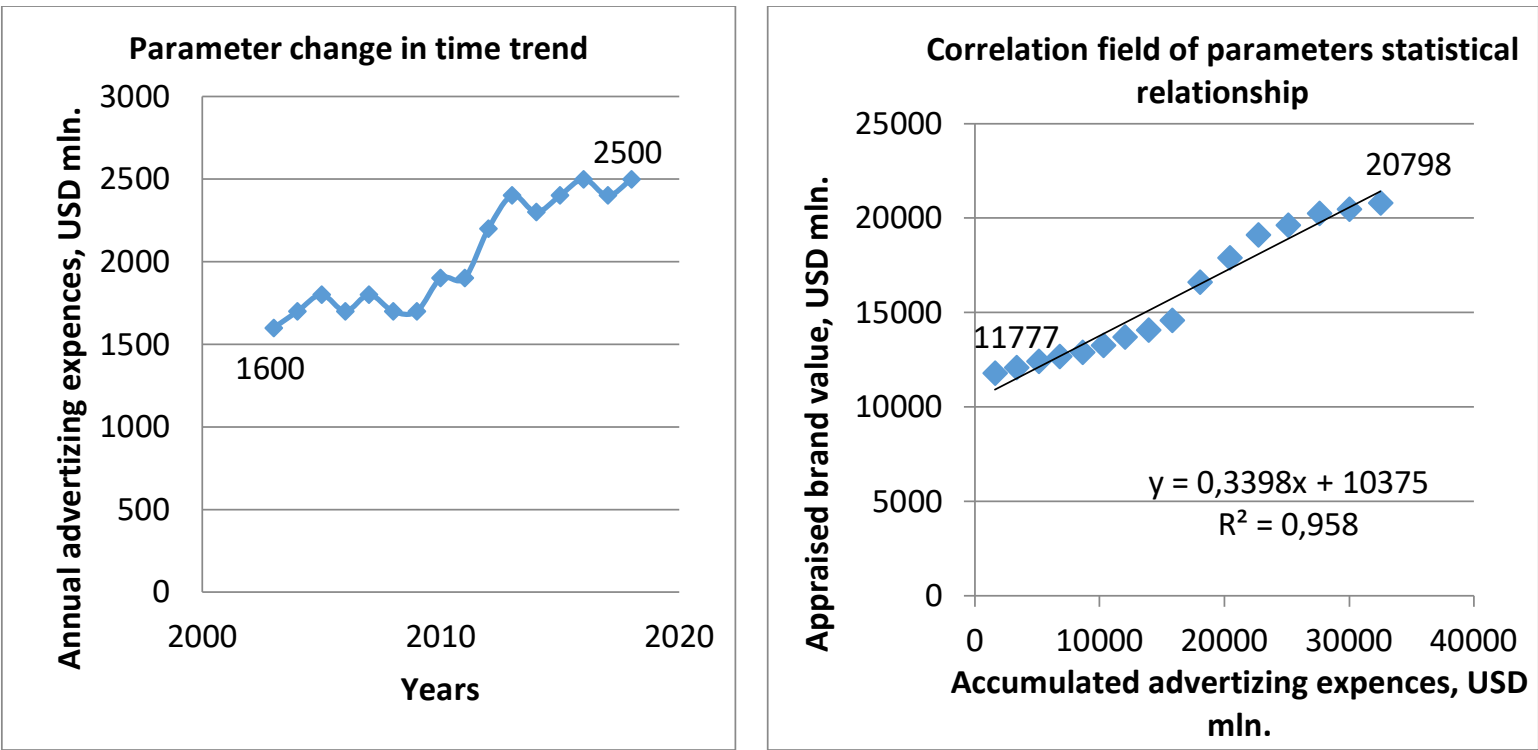

Figure 4: Annual advertisement expenses dynamics (left) and correlation field of accumulated during the whole retrospective period advertisement expenses and appraised brand value (right).

Source: diagrams are developed by the authors.

As we can see from a diagram on figure 4 (left), during a retrospective period 2003 2018 annual advertisement expenses dynamics is characterized by general increase tendency, with a small temporal reduction periods. Anyway, in spite of this, on figure 4 (right) is shown appraised brand value dependency from accumulated during the whole retrospective period advertisement expenses, which has a fully monotonous character. It testifies that statistical dependence of appraised brand value from accumulated during the whole retrospective period advertisement expenses is not critically sensible to the increase rates small changes of these expenses annual level.

\subsection{Brand Apple}

The most interesting is a researched indexes dynamics for brand Apple. In this case as a primary data were used indexes of Selling, General and Administrative expenses (SG\&A), published by Ycharts company (YCHARTS, 2018). Appraised brand value was taken from Brand Finance Global 500 (BRAND FINANCE, 2018). In according to the Brand Finance valuation procedure algorithm, appraised brand value is determined as a trade mark cost and marketing support is related to it intellectual property, within the limits of branding business. On diagrams figure 5 the trends of appraised brand value time change dynamics and brand annual absolute depreciation on retrospective period 2007 - 2018 are shown. 
INDEPENDENT JOURNAL OF MANAGEMENT \& PRODUCTION (IJM\&P)

http://www.ijmp.jor.br

v. 11, n. 6, September - October 2020

ISSN: 2236-269X

DOI: $10.14807 /$ ijmp.v11i6.1170
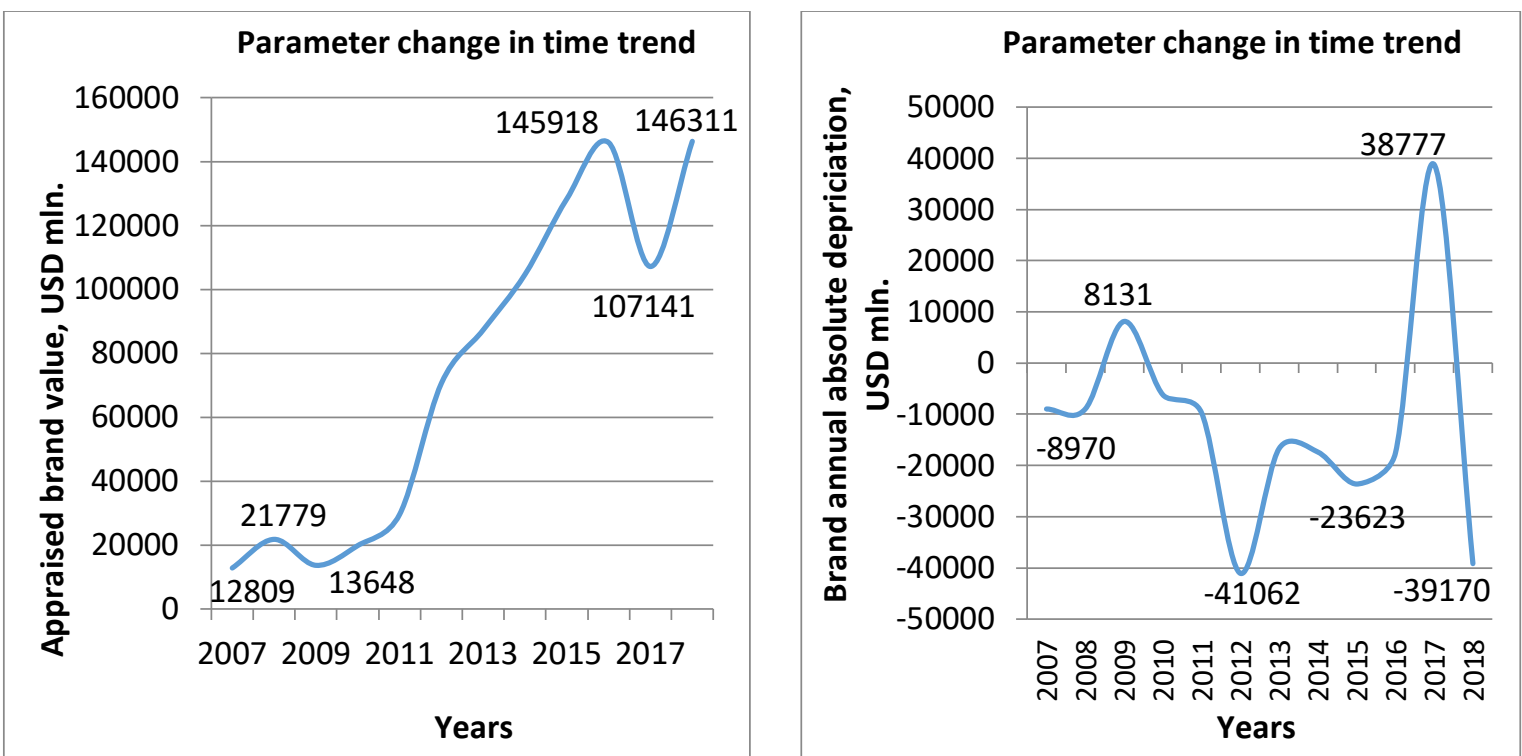

Figure 5: Appraised brand value dynamics (left) and brand annual absolute depreciation on retrospective period (right).

Source: diagrams are developed by the authors.

As well as for the preliminary considered brands, in this case during a 2007 - 2018 retrospective period there was observed a general tendency of appraised brand value increase, but value time change function was not monotonous. Two one-year short-time periods of positive annual depreciation and appraised brand value decline took place during the retrospective period. In 2009 brand value decline took place, to 13648 USD mln from a previous index in 2008, that was presented by 21779 USD mln. Also in 2017 a sharper decline took place, to 107141 USD mln from a previous index in 2016, that was presented by 145918 USD mln.

It means that fluctuations of appraised brand value time changes function were observed - we can see not only brand value rates increase, but also multiple changes of its dynamics direction. In first case its decline resulted in the receipt of positive index of brand annual absolute depreciation up to 8131 USD mln in 2009, and in second case - accordingly, up to 38 777 USD mln in 2017. Thus, the values of brand annual absolute depreciation index during retrospective period also carried out alternating character, with the repeatedly changes of depreciation sign.

Predominantly, value of brand annual absolute depreciation was negative, that corresponds to the general tendency of brand value increase on the long-time gap. But observed in figure 5 (left) double short-time decline of appraised brand value entailed appearance of brand annual absolute depreciation high positive values in 2009 and 2017. 
Let's analyze interconnection between positive brand annual absolute depreciation values appearance and the level of annual advertisement expenses. As it possible to see on figure 6 (left), in 2008 slowing down of annual advertisement expenses increase rates took place: increase of annual advertisement expenses was declined to 131 USD mln, id est its growth from previous index in 2007, that presented 1091 USD mln, to 1288 USD mln in 2008.

A similar situation was observed in 2016: we can see more considerable decline of annual advertisement expenses rates from previous index in 2015, that presented 3848 USD mln, to 3946 USD mln in 2016. Thus, exactly in 2008 and 2016 rates of annual advertisement expenses increase were minimal during the whole retrospective period. This fact explains the sharp fall-off decline of appraised brand value in next periods, in 2009 and 2017. In this case we look after a hard undoubted fact, that even not reduction of annual advertisement expenses, but its growth rates slowdown deceleration only causes a fully unambiguous reaction as brand value reduction and brand annual absolute depreciation increase already in a next period.

It testifies the extraordinarily high brand value sensitiveness to significant annual advertisement expenses growth rates. Coming from this, it is expedient to examine advertisement expenses as a basic primary price-forming factor of brand value. This example once again confirms the presence of direct interconnection between annual advertisement expenses and brand value - but, obviously, this relationship is not functional, but rather statistical.

In the brand Pepsi example above it was demonstrated statistical dependence presence of appraised brand value from accumulated during the whole retrospective period advertisement expenses, so brand value is not critically sensible to small changes of these expenses annual level. But as we see in the brand Apple example, the sizable changes of these expenses annual level - and, moreover, its reduction during few consecutive years - causes considerable decline of appraised brand value. Considered example also once again evidently demonstrates brands very special ability to find out its annual absolute depreciation alternating sign-changed character on a long-term gap interval.

The justice of the conclusion formulated higher can be led mathematically, expecting the numeral indexes of statistical data rows. On figure 6 (right) graphic interpretation of this dependence is presented - correlation field of accumulated during the whole retrospective period advertisement expenses and appraised brand value, with regression line equation characteristics and determination coefficient value. 
INDEPENDENT JOURNAL OF MANAGEMENT \& PRODUCTION (IJM\&P)

http://www.ijmp.jor.br

v. 11, n. 6, September - October 2020

ISSN: 2236-269X

DOI: $10.14807 /$ ijmp.v11i6.1170
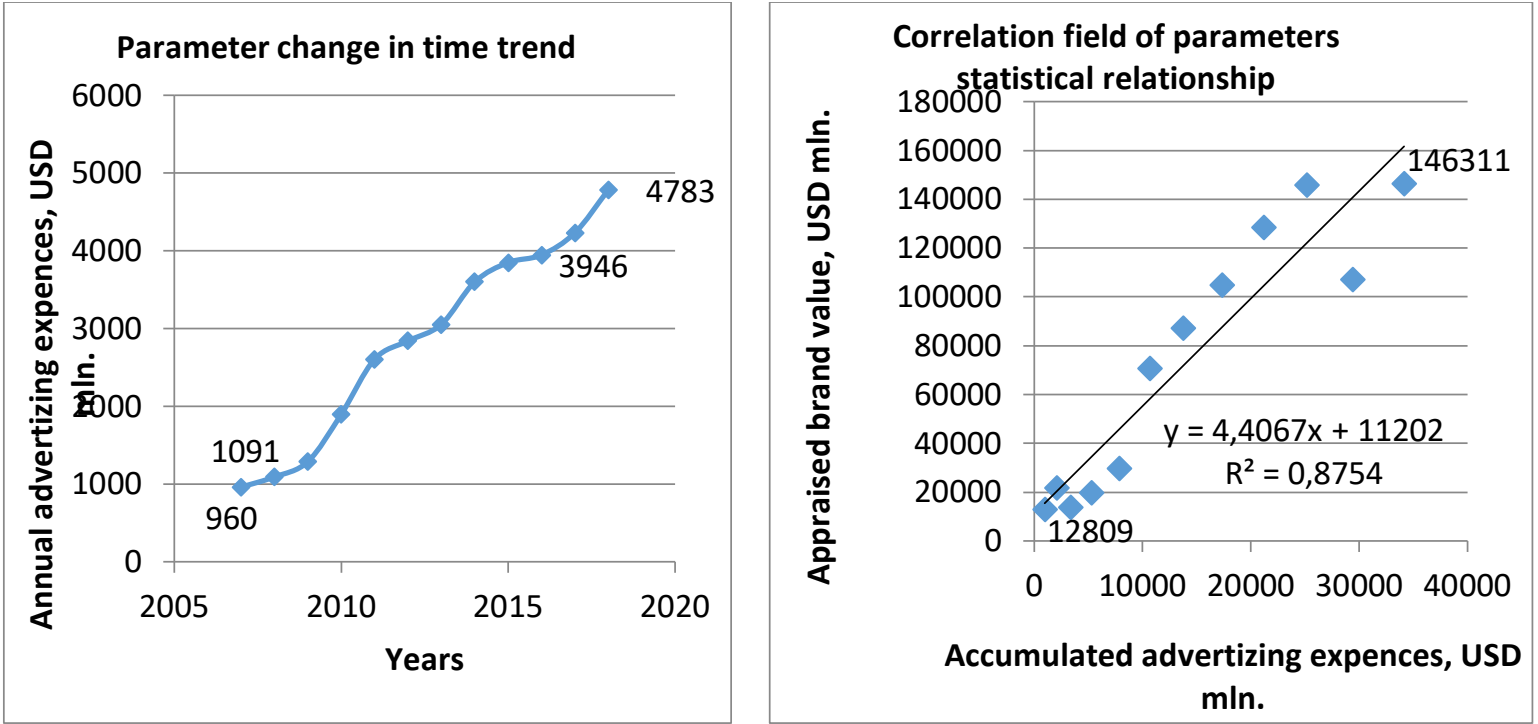

Figure 6: annual advertisement expenses dynamics (left) and correlation field of accumulated during the whole retrospective period advertisement expenses and appraised brand value (right).

Source: diagrams are developed by the authors.

\section{DATA PROCESSING AND GENERALIZATION}

The analysis of appraised brand value indexes dynamics confirms the very special character of this intangible asset and unique this class assets ability to demonstrate positive and negative sign depreciation in separate periods during its economic life duration, id est value reduction or increase in time. Thus direction of appraised brand value changes - its reduction or increase - determines the sign of annual absolute depreciation quantitative indexes. For the most successful companies, at predominance of their trademarks value increase tendencies, annual absolute depreciation indexes are often negative; during periods of brand value temporal decline, indexes of annual absolute depreciation are positive.

As an analysis of most expensive brand appraised value changes dynamics showed, in general case for enterprises that are characterized by the stable economy growth rates, typical is a presence of steady trend tendency to the permanent appraised value of these assets increase. It takes place, first of all, due to its value upbuilding by accumulation in its cost brands owner's investment cash flows, intended to its advertizing and information support. It grounds to research more attentive the cross-correlation indexes between advertisement expenses, which are the part of SG\&A charges, and appraised brand value.

Descriptions of annual advertisement expenses rows of current year and accumulated during a whole retrospective period advertisement expenses are considered below, with the aim to determine its statistical closeness to the appraised brand value row. 
ISSN: 2236-269X

DOI: $10.14807 /$ ijmp.v11i6.1170

Table 1: Statistical characteristics of annual / accumulated during a whole retrospective period advertisement expenses rows and its cross-correlation relationship closeness with appraised brand value indexes.

\begin{tabular}{|c|c|c|c|c|}
\hline Parameter indicators / Indexes & $\begin{array}{l}\text { Unit of } \\
\text { measurement }\end{array}$ & Samsung & Pepsi & Apple \\
\hline Retrospective period beginning date & Year & 2010 & 2003 & 2007 \\
\hline Retrospective period end date & Year & 2018 & 2018 & 2018 \\
\hline $\begin{array}{l}\text { Minimum value of annual advertisement } \\
\text { expenses row }\end{array}$ & USD mln & 2322 & 1600 & 960 \\
\hline $\begin{array}{l}\text { Maximum value of annual advertisement } \\
\text { expenses row }\end{array}$ & USD mln & 4798 & 2500 & 4783 \\
\hline $\begin{array}{l}\text { Minimum value of accumulated during a } \\
\text { whole retrospective period advertisement } \\
\text { expenses row }\end{array}$ & USD mln & 2322 & 1600 & 960 \\
\hline $\begin{array}{l}\text { Maximum value of accumulated during a } \\
\text { whole retrospective period advertisement } \\
\text { expenses row }\end{array}$ & USD mln & 30989 & 32500 & 34141 \\
\hline $\begin{array}{l}\text { Minimum value of appraised brand value } \\
\text { row }\end{array}$ & USD mln & 19491 & 11777 & 12809 \\
\hline $\begin{array}{l}\text { Maximum value of appraised brand value } \\
\text { row }\end{array}$ & USD mln & 59890 & 20798 & 146311 \\
\hline $\begin{array}{l}\text { Mathematical expectation of annual } \\
\text { advertisement expenses row estimation }\end{array}$ & USD mln & 3443 & 2031 & 2845 \\
\hline $\begin{array}{l}\text { Mathematical expectation of accumulated } \\
\text { advertisement expenses row estimation }\end{array}$ & USD mln & 16361 & 15856 & 14248 \\
\hline $\begin{array}{l}\text { Mathematical expectation of appraised } \\
\text { brand value row estimation }\end{array}$ & USD mln & 41570 & 15763 & 73989 \\
\hline $\begin{array}{l}\text { Sample variance / dispersion of annual } \\
\text { advertisement expenses row estimation }\end{array}$ & USD mln ${ }^{2}$ & 726335 & 107148 & 1543380 \\
\hline $\begin{array}{l}\text { Sample variance / dispersion of } \\
\text { accumulated advertisement expenses row } \\
\text { estimation }\end{array}$ & USD mln ${ }^{2}$ & 83284912 & 89583711 & 114968035 \\
\hline $\begin{array}{l}\text { Sample variance / dispersion of appraised } \\
\text { brand value row estimation }\end{array}$ & $\mathrm{USD}_{\mathrm{mln}}{ }^{2}$ & 175624894 & 10797292 & $\begin{array}{r}2550221 \\
824 \\
\end{array}$ \\
\hline $\begin{array}{l}\text { Corrected sample variance / dispersion of } \\
\text { annual advertisement expenses row } \\
\text { estimation }\end{array}$ & $\mathrm{USD}_{\mathrm{mln}}{ }^{2}$ & 817126 & 114292 & 1683687 \\
\hline $\begin{array}{l}\text { Corrected sample variance / dispersion of } \\
\text { accumulated advertisement expenses row } \\
\text { estimation }\end{array}$ & USD $\mathrm{mln}^{2}$ & 93695526 & 95555958 & 125419675 \\
\hline $\begin{array}{l}\text { Corrected sample variance / dispersion of } \\
\text { appraised brand value row estimation }\end{array}$ & $\mathrm{USD}_{\mathrm{mln}}{ }^{2}$ & 197578006 & 11517111 & $\begin{array}{r}2782060 \\
171 \\
\end{array}$ \\
\hline $\begin{array}{l}\text { Standard deviation of annual } \\
\text { advertisement expenses row estimation }\end{array}$ & USD mln & 904 & 338 & 1298 \\
\hline $\begin{array}{l}\text { Standard deviation of accumulated } \\
\text { advertisement expenses row estimation }\end{array}$ & USD mln & 9680 & 9775 & 11199 \\
\hline $\begin{array}{l}\text { Standard deviation of appraised brand } \\
\text { value row estimation }\end{array}$ & USD mln & 14056 & 3394 & 52745 \\
\hline $\begin{array}{l}\text { Variation coefficient of annual } \\
\text { advertisement expenses row estimation }\end{array}$ & $\%$ & 26,253 & 16,643 & 45,607 \\
\hline $\begin{array}{l}\text { Variation coefficient of accumulated } \\
\text { advertisement expenses row estimation }\end{array}$ & $\%$ & 59,163 & 61,649 & 78,600 \\
\hline $\begin{array}{l}\text { Variation coefficient of appraised brand } \\
\text { value row estimation }\end{array}$ & $\%$ & 33,813 & 21,530 & 71,288 \\
\hline
\end{tabular}


ISSN: 2236-269X

DOI: 10.14807/ijmp.v11i6.1170

\begin{tabular}{|l|l|r|r|r|}
\hline $\begin{array}{l}\text { Linear pair correlation coefficient of } \\
\text { annual advertisement expenses and } \\
\text { appraised brand value rows estimation }\end{array}$ & - & 0,408 & 0,974 & 0,941 \\
\hline $\begin{array}{l}\text { Linear pair correlation coefficient of } \\
\text { accumulated advertisement expenses and } \\
\text { appraised brand value rows estimation }\end{array}$ & - & 0,984 & 0,979 & 0,936 \\
\hline $\begin{array}{l}\text { Determination coefficient of annual } \\
\text { advertisement expenses and appraised } \\
\text { brand value rows estimation }\end{array}$ & - & 0,167 & 0,948 & 0,886 \\
\hline $\begin{array}{l}\text { Determination coefficient of accumulated } \\
\text { advertisement expenses and appraised } \\
\text { brand value rows estimation }\end{array}$ & - & 0,968 & 0,958 & 0,875 \\
\hline
\end{tabular}

Source: table data are developed by the authors.

\section{INTERPRETATION OF DATA RECEIVED AND DISCUSSION}

First of all, it's necessary to note that for all brands are considered here variation coefficient of appraised brand value row estimation is higher than variation coefficient of annual advertisement expenses row estimation. It specifies on that in every case during the retrospective periods appraised brand value changed stronger, than value of annual advertisement expenses rate.

As it’s evidently from annual advertisement expenses trends diagrams given higher, all of them demonstrate a general tendency to the increase in time, sometimes - with substantial fluctuations. But appraised brand value increase, caused by this annual advertisement expenses increase, in every case was stronger - if to compare the increase rates in relative expression.

Actually, this fact we interpret as clear evidence of brands use economic efficiency and feasibility of investing in intellectual property objects, aimed its information support and advertising. By the ratio index of variation coefficient of appraised brand value row estimation to variation coefficient of annual advertisement expenses row estimation, which value is greater than one for all analyzed brands, the fact of brands economic efficiency is mathematically confirmed. Respectively, index of variation coefficient of appraised brand value row estimation for each of brands considered above is less than variation coefficient of accumulated advertisement expenses row estimation.

So, its ratio index is less than one for all analyzed brands. It means that the cash flows are invested in brand information support and development provide to this intangible asset owner high relative profitability, as appraised brand value growth in every retrospective period is considerably higher, than sum of annual advertisement expenses in this period. Even if not taking into account other enormous preferences of economic and non-economic character, one and only index of appraised brand value increase beyond controversy confirms its high 
DOI: 10.14807/ijmp.v11i6.1170

economic efficiency. And the passing ahead brand value high growth rates, thus, fully justify the large cash flows on an advertisement and brand information support, as these money are accumulated in the brand value and actually these funds remain available to intellectual property object owner.

Objective regularity law is educed higher, on the other hand, indicates inappropriate of annual advertisement expenses index direct use as main price-forming factor that can be applied at the brand evaluation by Costs approach. As a brand value grows in time with relatively more rapid rates, than annual advertisement expenses index, statistical relationship between these two parameters is less close, than at application of accumulated advertisement expenses index.

It's easy to verify that, comparing the values of linear pair correlation coefficients of annual advertisement expenses/appraised brand value and accumulated advertisement expenses rows/appraised brand value rows. As we can see in table 1, linear pair correlation coefficients of accumulated advertisement expenses row are higher, what means more close statistical relationship between this parameter and appraised brand value. About it greater closeness evidenced higher values of linear pair correlation coefficients and, accordingly, determination coefficients for the brands of Samsung and Pepsi. And only in case of Apple brand there is a reverse picture - insignificant exceeding of these coefficients in case of the use of annual advertisement expenses.

The last fact it is possible to explain by the next features of this case. As evidently from the diagram charts figure 5, 6 of time change dependences of corresponding parameters, value of Apple annual advertisement expenses shows stably and monotonously increase during the whole retrospective period - so, the variation coefficient of this row presents $45,6 \%$, the highest of all considered higher brands. In the same time appraised brand value also had a general tendency to the increase, but it was not monotonous - the considerable fluctuations of increase rates took place, and even twice one-year short-time periods of positive annual depreciation and appraised brand value temporal decline was observed during the retrospective period.

Therefore high variation coefficient of appraised brand value row in $71,3 \%$ is not caused by the high growth rates of this index increase, but rather by its fluctuations with the changes of annual depreciation sign at function inflection points - transition moments from the periods of brand value increase to the periods of its reduction. As it's evidently from the diagram chart figure 5 (right) of annual absolute depreciation this parameter in case of Apple 
DOI: 10.14807/ijmp.v11i6.1170

carried the sharply expressed alternating character, with the very considerable scope of fluctuations, no typical for two other brands considered higher. Ratio index of appraised brand value row variation coefficient to the annual advertisement expenses row variation coefficient in this case is the greatest $(1,563)$ among three analyzable brands, and ratio index of appraised brand value row variation coefficient to the accumulated advertisement expenses row variation coefficient in this case is the lowest $(0,907)$.

Nevertheless value of Apple linear pair correlation coefficients of appraised brand value row and of annual $(0,941)$ and accumulated $(0,936)$ advertisement expenses rows in this case are extremely high and very close to each other. When rounding to two decimal places, they will be equal $(0,94)$. In our opinion, it means no possibility of using annual advertisement expenses index as main price-forming factor that can be applied at the brand evaluation by Costs approach, instead accumulated advertisement expenses. Closeness of these linear pair correlation coefficients indexes testifies only the statistical relationship closeness similarity between these two parameters, which in every case is predefined by the time trends functions type. In this case a function that describes law conformity of annual advertisement expenses increase, by its very unstable character with substantial fluctuations, turned out to be closer to the appraised brand value trend function, than analogical function of accumulated advertisement expenses.

\section{CONCLUSIONS}

Anyway, as a primary market data at the brand evaluation by Costs approach in general case may be recommended to use exactly accumulated advertisement expenses indexes, because independent expert evaluation fundamental basic principles envisages taking into account the sum of all expenses, related to appraised asset creation and support, aimed at its utility increasing. In application to the brand evaluation it means the necessity to consider in calculations such kinds of expenses, as: logo development; trade mark official registration; legal defense; current legal support service; time extending of a protection title document, and others like that.

Thus under "expenses, aimed at brand utility increasing expenses" we mean the totality of all expenses, related to this intellectual property object support - especially, cash flows were invested in its development, advertisement and all kinds of brand information support, during the whole period of appraised asset existence. This certainly includes all support activities, related to the brand utility increase and its market value growth - in particular, advertisement 
campaigns in mass medias realization, hidden advertisement in artistic works, company participating in various competitions, contests, ratings, socially oriented initiatives, any charity activity and others. It does not conflict with the requirements of brand valuation standards (ISO 10668, 2010).

Theoretical basis of this fundamentally important thesis are the basic principles of independent expert evaluation principles, fixed as fundamental grounding of Costs approach namely, principles of Utility, Substitution and The Highest and of The Best Use (FRIEDMAN; ORDWAY, 1995). Exactly on the basis of these fundamental principles the main supposition of Costs approach is proved, in obedience to that is accepted and grounded, that with certain initial conditions and limitations, the appraised asset market value is determined by the accumulated sum of the indicated higher expenses types, accumulated in its cost during the whole period of economic life, up to the evaluation date.

Will notice that in the classic price-forming theory, from this amount should be excluded appraised asset depreciation/obsolescence index, calculated on the evaluation date. But, as for such very special intangible assets, as a brand and goodwill, with their unique ability to demonstrate positive and negative sign depreciation in separate periods during its economic life, numerical indexes of depreciation, as shown above, mostly are negative. So, a natural consequence of this is not a reduction, but, vice versa - increase of asset market value.

This thesis is confirmed by the functions graphics on diagram charts given higher. It is the important methodological difference of this class intangible assets evaluation, that certainly must be taken into account at Costs approach performing - contrary to the accounting data of assets record-keeping, that envisage a positive depreciation with charging amortization presence exceptionally. From the modern independent evaluation conception point of view, those book-keeping accounting data, confirming brands positive depreciation, are absolutely fictitious.

The last statement is fully consistent with data of Alfred M. King, in whose opinion, intellectual property objects - brands, trademarks, etc. - are intangible assets with the indefinite term of the useful economic lifetime, so it must not be subjects of amortization and <positive> depreciation. Author considers that enterprises cannot represent the fact of appraised brand value increase in current accounting reports, however they can at least not amortize its cost, while there are prospects for its effective use during indefinite time period in the future (KING, 2011). We suppose that it’s high time to do the next step - to admit the fact of brands positive 
DOI: 10.14807/ijmp.v11i6.1170

annual depreciation presence and take it into account at brand evaluation by Costs approach current practice.

For the decision of contradiction between the record-keeping standards requirements, that does not imply the actual negative depreciation presence for some specific types of intangible assets, it is possible to recommend implementation of these assets periodic annual revaluation, with the use of independent expert evaluation methods and instruments - that is allowed by requirements pp. 107, 108 IAS 38 (IAS 38, 2017).

The operating documents of accounting reports normative base do not contain any possibility of assets value increase in time, id est its negative depreciation, but also none of record-keeping standards forbids specify its fair market value, even in case if it increased on a period between two evaluations, as it is demonstrated by the results of the executed research. Thus, (FISHMAN et al., 2000) firmly established that in some cases separately identified intangible assets value can be corrected in direction of its appraised value.

Research results ground to consider that economic measuring evaluation estimations reliability in case of application accumulated advertisement expenses index as main priceforming factor at Costs approach performing will be the highest. In fact exactly this parameter is most closely statistically associated with the brand market value. We suppose that results of researches, and especially the above mentioned valuation/appraising method, become the base for the further independent evaluation methodology development.

\section{REFERENCES}

BOJARSKIJ, J. A. (1972) Porjadkovye statistiki. Matematicheskaja statistika dlja jekonomistov [Ordered statistics. Mathematical statistics for economists]. Moscow: Statistika, p. 118.

BRAND FINANCE LATEST RELEASES. (2018) Global 500. 2018. The annual report on the world's most valuable brands. Available: https://brandfinance.com/knowledgecentre/reports/brand-finance-global-500-2018/.

DAMODARAN, A. (2009) Valuing Companies with intangible assets. Available: $<$ http://pages.stern.nyu.edu/ adamodar/>.

FARHUTDINOV, I. Z.; TRAPEZNIKOV, V. A. (2006) Investicionnoe pravo [Investment law]. Moscow: Volters Kluver. p. 116.

FINK, C.; FOSFURI, A.; HELMERS, C.; MYERS, A. F. (2018) Submarine trademarks. Economic Research Working Paper No. 51. World Intellectual Property Organization (WIPO). Available: https://www.wipo.int/ edocs/pubdocs/en/wipo_pub_econstat_wp_51.pdf.

FISHMAN, J. E.; PRATT, S. P.; GRIFFITH, J. C.; WILSON, D. K. (2000) Guide to business valuations. Trans from Eng. Moscow: ZAO «Kvinto-konsalting», $388 \mathrm{~s}$. 
FRIEDMAN, J. P.; ORDWAY, N. (1995) Income Property. Appraisal and analysis. Trans from Eng. Moscow: Delo Ltd, $480 \mathrm{~s}$.

GEHANI, R. R. (2016) Corporate Brand Value Shifting from Identity to Innovation Capability: from Coca-Cola to Apple. Journal of Technology Management \& Innovation, v. 11, n. 3, p. 11-20. Available: http://www.redalyc.org/pdf/847/84748406002.pdf.

IAS38 (2017) International Accounting Standard 38. Intangible Assets. Available: https://mf.rks-gov.net/.../5D08BF1E-81EB-4EE4-BAE3-56446B78FF65.doc.

INTERBRAND. (2018) Interbrand Releases: 2018 Best Global Brands Report. Available: https://www.interbrand.com.

ISO10668. (2010) International standard. Brand valuation. Requirements for monetary brand valuation. Available: http://farsi.tpo.ir/uploads/iso\%5B1\%5D.pdf.

KING, A M. (2011) Fair Value for Financial Reporting: Meeting the New FASB

Requirements. Trans from Eng. Moscow: Al'pina Publisherz, p. 269.

KUMAR, R (2015) Valuation: Theories and Concepts. Academic Press. p. 307. Available: https://books.google.com.ua/books?id=gFciBQAAQBAJ\&pg=PA332\&lpg=

PA307\&ots=purxxFB1Gl\&focus=viewport\&dq=samsung+valuation\&hl=uk\&output=html_te xt.

LAPISHKO, M. L. (1995) Osnovy finansovo-statystychnogo analizu ekonomichnyh procesiv [Economic processes financially-statistical analysis bases]. L'viv: Svit, p. 328.

MAGNUS J. A. R.; KATYSHEV, P. K.; PERESECKIJ, A. A. (2004) Jekonometrika. Nachal'nyj kurs. [Econometrics. Initial course]. Moscow: Delo Ltd. 576 p.

POZDNYAKOV, Y. V. (2019) Opredelenie iznosa ob’ektov intellektual'noj sobstvennosti: jekonometricheskij podhod. [Intellectual property objects depreciation determination: econometric approach]. Ekonomika i banki. [Economy and banks]. No.1, 91 - 100. Available: http://ojs.polessu.by/EB/issue/view/129.

POZDNYAKOV, Y. V.; LAPISHKO, M. L. (2018a) Vplyv vydiv znosu tovarnogo znaka na zminu jogo vartosti $v$ chasi [Trademark depreciation types influence on its value time changes model choice]. Shidna Jevropa: ekonomika, biznes ta upravlinnja [Eastern Europe: economy, business and management], v. 6, n. 17, p. 728-735. Available: http:// www.easterneurope-ebm.in.ua/17-2018-ukr.

POZDNYAKOV, Y. V.; LAPISHKO, M. L. (2018b) Uzgodzhennja kolizii' normatyvnyh vymog do vyznachennja vartosti tovarnogo znaka [Concordance possibilities of normative bases collision for trademark cost determination]. Ekonomichnyj analiz [Economic analysis], v. 28, n. 4, p. 43-49.

POZDNYAKOV, Y. V.; LAPISHKO, M. L. (2019a) Vplyv dynamiky zminy vartosti brenda na pokaznyky jogo znosu [Brand name value dynamic time changes influence on it's depreciation indexes]. Infrastruktura rynku [Market Infrastructure], v. 28, p. 393-401. Available: http://www.market-infr.od.ua/uk/28-2019.

POZDNYAKOV, Y. V.; LAPISHKO, M. L. (2019b) Statystychnyj vzajemozv’jazok pohybok ekspertnoi' ocinky vartosti najdorozhchyh brendiv svitu [Statistical relationship of most valuable global brands expert valuation results errors]. East European Scientific Journal, v. 5, n. 45, part 10, p. 37-45. Available: https://eesa-journal.com/wpcontent/uploads/EESA_may10.pdf. 
POZDNYAKOV, Y. V.; LAPISHKO, M. L. (2019c) Statystychnyj zv'jazok rezul'tativ ocinky vartosti brendiv z i'h absoljutnymy pohybkamy [Brands valuation results statistical relationship with their absolute errors]. Ekonomika ta suspil'stvo [Economy and society], n. 20, 100. Available: http://economyandsociety.in.ua.

POZDNYAKOV, YU. V.; LAPISHKO, M. L.; SKYBINSKA, Z. M. (2019) Crosscorrelation relationship between intellectual property objects value and its price-forming factors. Economics, Entrepreneurship, Management, v. 6, n. 1, p. 88-103. DOI: https://doi.org/10.23939/eem2019.01.088. Available: http://science.lpnu.ua/uk/eem/vsivypusky/vypusk-6-nomer-1-2019/cross-correlation-relationship-between-intellectualproperty.

POZDNYAKOV, Y. V.; SADOVENKO, Y. P. (2018a) Vyznachennja terminu korysnogo vykorystannja nematerial'nyh aktyviv z vid'jemnym znosom [Useful using terms determination of intangible assets with a negative depreciation]. Visnyk social'noekonomichnyh doslidzhen' [Socio-economic research bulletin]. Odessa National Economic University, v. 2, n. 66, p. 65-76.

POZDNYAKOV, Y. V.; SADOVENKO, Y. P. (2018b) Analiz rozbizhnostej al'ternatyvnyh ocinok vartosti nematerial'nyh aktyviv [Divergences of intangible assets evaluation alternative results analysis]. Visnyk Odes'kogo nacional'nogo universytetu. Ekonomika. [Announcer of the Odesa national university. Economy], v. 23, n. 7, p. 192-197.

POZDNYAKOV, Y. V.; SADOVENKO, Y. P. (2018c) Kil'kisna ocinka tochnosti vyznachennja vartosti ob'jektiv intelektual'noi' vlasnosti [Quantitative estimation of intellectual property objects evaluation accuracy]. Ekonomika ta suspil'stvo [Economy and society], n. 19, 216. Available: http://economyandsociety.in.ua.

POZDNYAKOV, Y. V.; SADOVENKO, Y. P. (2019) Doslidzhennja funkcij gustyny rozpodilu imovirnostej vidnosnyh pohybok al'ternatyvnyh ocinok vartosti brendiv [Research of brands alternative value estimations relative errors probability distribution density functions]. Regional'na ekonomika ta upravlinnja [Regional economics and management], v. 1, n. 23, p. 161-169.

POZDNYAKOV, Y. V.; SKYBINS’KA, Z. M.; GRYNIV, T. T. (2019) Analiz funkcional'nogo vzajemozv'jazku pohybok al'ternatyvnyh ocinok vartosti brendiv [Functional relationship of brands valuation alternative estimations errors analysis]. Shidna Jevropa: ekonomika, biznes ta upravlinnja [Eastern Europe: economy, business and management], v. 5, n. 22, p. 280-289. Available: http:// www.easterneurope-ebm.in.ua/22-2019-ukr.

PRATAP, A. (2018) Pepsico advertising and marketing budget. Marketing and Advertising Budget of Pepsi 2003-2017. Notesmatic. Available: https://notesmatic.com/pepsico-advertising-and-marketing-budget/.

PRATAP, A (2019) Samsung Marketing expenses. Notesmatic. Available: https://notesmatic.com > 2018/12 > samsung-marketing-expenses.

SIVEC, S. A. (2001) Statisticheskie metody v ocenke nedvizhimosti i biznesa. Uchebnoprakticheskoe posobie po statistike dlja ocenshhikov. [Statistical methods in the real estate and business valuation]. Zaporozh'e.- $320 \mathrm{~s}$.

SMITH, G. V. (1999) Intellectual Property Valuation. Franklin Pierce Law Center. Eighth Annual Advanced Licensing Institute. c. 26 Available:

$<$ http://www.ipmall.info/sites/default/files/hosted_resources/ALI_Presentations/ALI_1999/Pi erce_Law_1999_Intellectual\%20Property\%20Valuation.pdf>. 
ISSN: 2236-269X

DOI: 10.14807/ijmp.v11i6.1170

YCHARTS (2018) Apple Inc Historical SG\&A Expense (Quarterly) Data. Available: https://ycharts.com/companies/AAPL/sga_expense. 